\title{
Characterization of Pectobacterium carotovorum subsp. carotovorum as a new disease on Lettuce in Malaysia
}

\author{
Eisa Nazerian • Kamaruzaman Sijam • \\ Zainal Abidin Meor Ahmad • Ganesan Vadamalai
}

Received: 4 February 2011 / Accepted: 3 June 2013 / Published online: 18 October 2013

(C) Australasian Plant Pathology Society Inc. 2013

\begin{abstract}
Malaysia produces many varieties of vegetables. The Cameron Highland in the state of Pahang is the main area for lettuce (Lactuca sativa var. romana) production. A survey recently identified Pectobacterium spp. was responsible for more than $15 \%$ damage to lettuce both in the field (including greenhouses) and storage. Isolates of Pectobacterium carotovorum were collected from different greenhouses and fields and analysed in the laboratory during 2010. Nine isolates were purified and charcterised by morphological, biochemical and molecular methods. Pathogenicity studies on lettuce using 4 strains showed there was a high susceptibility to the $P$. carotovorum. PCR amplification with $\mathrm{Y}_{1}$ and $\mathrm{Y}_{2}$ primers (specific for $P$. carotovorum subspecies) produced the expected band of $434 \mathrm{bp}$. PCR amplification of the intergenic transcribed spacer region (ITS) using $\mathrm{G}_{1}$ and $\mathrm{L}_{1}$ primers also resulted in the expected two bands (535 and $580 \mathrm{bp}$ ). Based on these biochemical and physiological characteristics, PCR based pel gene, characterisation of the ITS region and digestion of the ITS-PCR products with $R s a \mathrm{I}$ restriction enzyme, all isolates were identified as $P$. carotovorum subsp. carotovorum. This is the first record of the bacterial pathogen causing disease on lettuce in Malaysia.
\end{abstract}

Keywords Vegetables · Detection - Identification - Bacterial disease

Bacterial soft rot diseases of plants are generally caused by bacteria in the genus Pectobacterium. The pathogen, $P$. carotovorum is one of the most important bacterial diseases of vegetables and causes rots in the field, during storage, and in transportation.

E. Nazerian $\cdot$ K. Sijam $(\bowtie) \cdot$ Z. A. Meor Ahmad $\cdot$ G. Vadamalai Department of Plant Protection, Faculty of Agriculture, University Putra Malaysia UPM, 43400 Seeding, Selangor, Malaysia e-mail:kama@agri.upm.edu.my
Originally described as Erwinia carotovora by Jones in 1901, taxonomic and molecular characterization of the genus Erwinia (Kwon et al. 1997; Hauben et al. 1998; Avrova et al. 2002; Gardan et al. 2003) has placed this bacterium into the genus Pectobacterium. Infections caused by Pectobacterium result in extensive maceration of the paranchymatus cells due to the production of enzymes such as proteases and pectinases (Kotoujansky 1987), resulting in cell deaths (Garibaldi and Battman 1971). Maceration depends on factors such as temperature and moisture (Perombelon 1980). Optimal temperatures for disease development are between 25 and $30{ }^{\circ} \mathrm{C}$. Control of soft rot is difficult as there are currently no effective chemical control measures available. However, cultural conditions which encourage plant growth, weed control, disease-free planting material, and the use of tolerant or resistant varieties offer the most effective control measures. Biochemical tests (Lelliot and Dickey 1984) were developed for the identification and characterization of $P$. carotovorum but do not discriminate between all Pectobacterium species. A PCR test based on the amplification of the pectatelyase-encoding gene ( $\mathrm{Pel}$ gene) however, does separate all Pectobacterium spp. except $P$. carotovorum subsp. betavascularum (Darrasse et al. 1994). Amplification of 16S-23S intergenic transcribed spacer (ITS, rRNA gene) is capable of separating $P$. carotovorum strains especially when combined with Restriction Fragment Length Polymorphism (RFLP) (Toth et al. 2001). The aims of this study were to detect, identify and characterize $P$. carotovorum isolated from soft rot infected lettuce by biochemical and molecular methods.

The objective of this study was to investigate the phenotypic and molecular characterization of the bacterial phytopathogen Pectobacterium carotovorum subsp. carotovorum, the causal agent of bacterial soft-rot on lettuce in Malaysia. Previously, P. carotovorum subsp. carotovorum was not determined as the causal agent of soft-rot on lettuce in Malaysia. In the present work the bacterium under study 
has been observed to play a very important role in soft rot disease incidence on lettuce in Malaysia.

The present study was therefore designed to identify the causal agent of soft rot in order to comprehend the etiological and disease management of $P$. carotovorum subsp. carotovorum in lettuce. The study was conducted with a survey of commercial lettuce production areas, and suspected samples were collected, analyzed and characterized by both biochemical and molecular methods

Samples of chlorotic or necrotic leaves with a light yellow color and exhibiting extensive water soaked lesions consistent with infection by Pectobacterium spp. were collected from a range of field sites and brought into the laboratory during 2010 for analysis. Small pieces of infected tissues were soaked in saline solution $(0.85 \% \mathrm{NaCl})$ for $20 \mathrm{~min}$ to allow bacterial cells to diffuse into the solution. A standard protocol using raffinose (RAF) and crystal violet pectate (CVP) media were used for isolation of the bacteria from plant samples (Segal 1971; Cuppels and Kelman 1974). Inoculated plates were incubated at $30{ }^{\circ} \mathrm{C}$ for 3 days and colonies that formed pits on CVP or were red on RAF were selected and sub-cultured at least twice to Luria-Bertani (LB) medium to obtain pure cultures for further testing. Cultures were stored in $20 \%$ glycerol at $-80{ }^{\circ} \mathrm{C}$ until required. Hypersensitivity reaction (HR) to Nicotiana tabacum cv. xanthi was tested by injecting a suspension of $10^{8} \mathrm{CFU} / \mathrm{ml}$ of bacterial under the leaf epidermis. All strains gave a positive reaction. Strains were also subjected to biochemical (Schaad et al. 2001), morphological and molecular assessments. Results of biochemical and morphological tests were as followings: bacteria were Gram negative, facultative anaerobic, rod shaped, oxidase negative, phosphatase negative, able to degrade pectate, sensitive to erythromycin, negative for utilization of $\alpha$-methyl glucoside and indole production, negative for reduction of sugars from sucrose, negative for acid production from arabitol and sorbitol, and positive from citrate, raffinose, and melibiose.

To test pathogenicity of the isolates leaves were surface sterilised with $70 \%$ ethyl alcohol, washed with sterilized distilled water, cut into small pieces, and inoculated with $20 \mu \mathrm{l}$ aliquots of a bacterial suspension (108 CFU/ml) (Luzzatto et al. 2007). Five representative strains were tested. Inoculated and uninoculated (control) leaves were placed

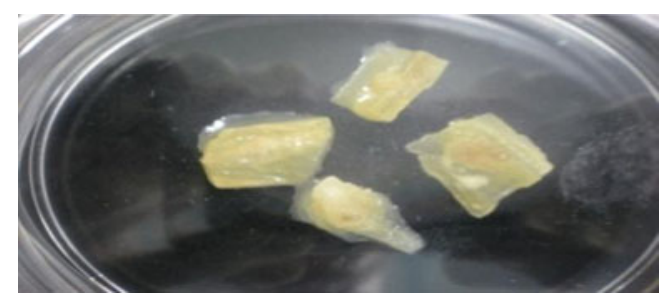

Fig. 1 Lettuce leaf slices inoculated with $20 \mu \mathrm{L}$ of $10^{8} \mathrm{CFU} / \mathrm{ml}$ of bacterial suspension. Photographed $36 \mathrm{~h}$ after inoculation

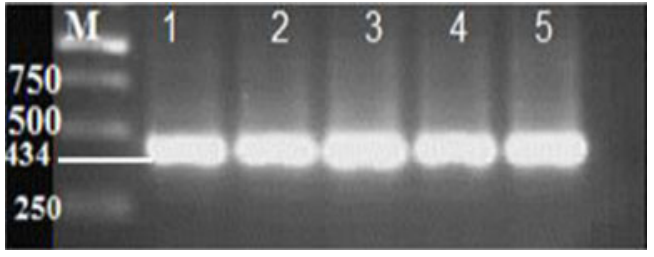

Fig. 2 Pectate lyase (pel) PCR amplification of five isolates of $P$. carotovorum subsp. carotovorum: M-molecular marker $1 \mathrm{~Kb}$, Lanes 1-5 P. carotovorum strains isolated from lettuce. All five strains characterized in this study were positive for $p e l$ gene amplification

in a growth chamber with $80-90 \%$ relative humidity at $27{ }^{\circ} \mathrm{C}$. Symptoms occurred $24 \mathrm{~h}$ after inoculation and were consistent with naturally occurring infections, whereas leaves inoculated with water remained healthy (Fig. 1). Koch's postulate was fulfilled with re-isolation of P. carotovorum which had the same characteristics as described earlier. PCR conditions for amplification of the pel gene followed the method of Darrasse et al. (1994). The two oligonucleotides Y1 and Y2 were used as primers. The amplified products were visualized electrophoresis on $1 \%$ agarose gels $\mathrm{w} / \mathrm{v}$ run in TG buffer $(3 \mathrm{gr} / \mathrm{li}$ Tris-Base $\mathrm{MW}=121.10,28.8 \mathrm{gr} / \mathrm{li}$ glycine $\mathrm{MW}=$ 75.07), stained with $1.0 \%$ ethidium bromide, visualized under uv light and photographed. The expected amplified fragment of approximately $434 \mathrm{bp}$ was obtained from all isolates (Fig. 2). To discriminate between P. carotovorum subsp. carotovorum and P. carotovorum subsp. odoriferum, all isolates were subjected to an $\alpha$-methyl glucoside test. ITSPCR was performed as described by Toth et al. (2001) using the universal primers G1 and L1. The product was visualized as described above, except on $2 \%$ agarose. As expected, two main bands were observed (Fig. 3). The ITS-PCR products were digestion with RsaI restriction enzyme. RFLP pattern analysis showed that all isolates from the lettuce samples gave the expected three banding pattern of 200,355, $520 \mathrm{bp}$. Based on biochemical and physiological characteristics, PCR based pel gene and analysis by ITS-PCR, all isolates were identified as P. carotovorum subsp. carotovorum. This is the first report of this bacterium causing a soft rot disease of lettuce in Malaysia. Because the symptoms caused by P. carotovorum resemble those of soft rot caused by other soft rot bacteria, The development of a specific, rapid diagnostic method for soft rot bacteria is noteworthy with regard to import and export

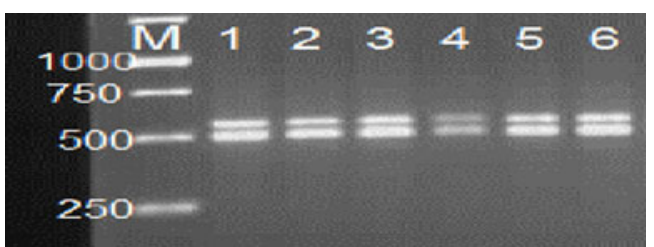

Fig. 3 ITS-PCR banding pattern of $P$. carotovorum subsp. carotovorum isolated from Lettuce: $\mathrm{M}$ - molecular marker $1 \mathrm{~kb}$, lanes 1-5 P. ccarotovorum subsp. carotovorum, lane 6- standard strain of $P$. ccarotovorum subsp. carotovorum (SCRI 1949) 
regulations for farm and greenhouse products. Results using primers $\mathrm{Y} 1 / \mathrm{Y} 2$, which amplified the expected bands from the isolates, were in accord with the classification based on physiological and biochemical features, and P. carotovorum was generally isolated from the infected lettuce. Due to the similarity in banding patterns between P. carotovorum and P. odoriferum in ITS-RFLP and the separation of these two from each other, the use of the $\alpha$ - methyl-D-glucoside test is suggested. Because of the high humidity and temperature, and prevalence of P. carotovorum in Malaysian fields and greenhouses, the disease is not unexpected. Therefore, using observations to determine the percentage of plants with soft rot caused by P. carotovorum in Malaysian farms and greenhouses is not conclusive, and complementary tests are needed to confirm the identity of the pathogen. Compared with biochemical and physiological tests, the PCR method with the use of suitable primers is preferred because it is cheaper and easier.

\section{References}

Avrova AO, Hyman LJ, Toth RL, Toth IK (2002) Application of amplified fragment polymorphism fingerprinting for taxonomy and identification of the soft rot bacteria Erwinia carotovora and Erwinia chrysanthemi. Appl Environ Microbiol 68:1499-1508

Cuppels D, Kelman A (1974) Evaluation of selective media for isolation of soft rot bacteria from soil and plant tissue. Phytopathology 64:468-475

Darrasse A, Priou S, Kotoujansky A, Bertheau Y (1994) PCR and Restriction Fragment Polymorphism of a pel gene as a tool to identify Erwinia carotovora in relation to potato diseases. Appl Environ Microbiol 60:1437-1443

Gardan L, Gouy C, Christen R, Samson R (2003) Elevation of three sub species of Pectobacterium carotovorum to species level: Pectobacterium atrosepticum sp. nov., Pectobacterium betavascularum sp. nov., and Pectobact- eriumwasabiae sp. nov. Int J Syst Evol Microbiol 53:381-391

Garibaldi A, Battman DF (1971) Pectic enzymes produced by Erwinia chrysanthemi and their effect on plant tissue. Physiol Plant Pathol 1:25-40

Hauben L, More ER, Vauterin L, Steenackers M, Mergaert J, Verdonck L, Swings J (1998) Phylogenetic position of phytopathogens within the Enterobacteriaceae. Syst Appl Microbiol 21 (3):384-397

Kotoujansky A (1987) Molecular genetics of pathogenesis by soft rot Erwinia. Ann Rev Phytopathol 25:405-430

Kwon SW, Go SJ, Kang HW, Ryu JC, Jo JK (1997) Phylogenetic analysis of Erwiniaspecies based on 16s rRNA gene sequences. Int J Syst Bacteriol 47:1061-1067

Lelliot RA, Dickey RS (1984) Genus VII. Erwinia. In: Krieg NR, Holt JG (eds) Bergey's manual of systematic bacteriology, vol 1. Williams \& Wilkins, Baltimore, pp 469-476

Luzzatto T, Yashya M, Lipsky A, Ion A, Belausov E, Yedidia I (2007) Efficient, long-lasting resistance against the soft rot bacterium Pectobacterium carotovorum in Calla lily provided by the plant activator methyl jasmonate. Plant Pathol 56:692-701

Perombelon MCM (1980) Ecology of the soft rot Erwinias. Annu Rev Phytopathol 18:361-387

Schaad NW, Jones JB, Chun W (2001) Laboratory guide for identification of plant pathogenic bacteria, 3rd edn. The American Phytopathological Society Press, St. Paul

Segal RH (1971) Selective medium for enumerating Erwinia species commonly found in vegetable packing-water. Phytopathology 61:425-426

Toth IK, Avrova AO, Hyman LJ (2001) Rapid identification and differentiation of the soft rot Erwinias by 16S-23S Intergenic Transcribed Spacer-PCR and Restriction Fragment Length Polymorphism Analysis. Appl Environ Microbiol 67:4070-4076 